\title{
Pengaruh Tingkat Stres dan Kadar Kortisol dengan Jumlah Folikel Dominan pada Penderita Infertilitas yang Menjalani Fertilisasi Invitro
}

\author{
Awik Setiyono', Hendy Hendarto', Budi Prasetyo', Margarita M. Maramis ${ }^{2}$ \\ 'Departemen Obsterti dan Ginekologi, Fakultas Kedokteran Universitas Airlangga, RSUD Dr. Soetomo Surabaya \\ ${ }^{2}$ Departmen Ilmu Kesehatan Jiwa, Fakultas Kedokteran, Universitas Airlangga, RSUD Dr. Soetomo Surabaya
}

\begin{abstract}
ABSTRAK
Tujuan: Mempelajari hubungan antara tingkat stres dan kadar kortisol darah dengan jumlah folikel dominan pada pasien infertilitas yang menjalani prosedur fertilisasi in vitro

Bahan dan Metode: Studi ini merupakan penelitian analitik cross sectionaldi dua klinik infertilitas di Surabaya selama 4 bulan. Didapatkan 30 subyek penelitian yang diambil data mengenai tingkat stres dengan menggunakan 2 kuisioner yaitu Percieved Stres Scale-10 (PSS-10) dan Infertility Reaction Scale (IRS) dan kadar kortisol darah sewaktu pagi. Subyek penelitian kemudian menjalani prosedur stimulasi ovarium dan dilakukan penghitungan jumlah folikel dominan sebelum dilakukan tindakan ovum pick up

Hasil: Dengan menggunakan hasil analisa statistik korelasi Spearman didapatkan hasil hubungan negatif antara tingkat stres menggunakan skoring PSS-10 $(\mathrm{r}=0,64 ; \mathrm{p}<0,01)$ dan juga IRS $(\mathrm{r}=0,83 ; \mathrm{p}<0,01)$ dengan jumlah folikel dominan. Didapatkan pula hubungan negatif antara kadar kortisol darah dengan jumlah folikel dominan $(r=0,80 \mathrm{p}<0,01)$.

Simpulan: Tingkat stres dapat berdampak pada jumlah folikel dominan. Kadar kortisol yang tinggi dapat menyebabkan jumlah folikel dominan semakin menurun.
\end{abstract}

Kata Kunci: Tingkat stres, kortisol, folikel dominan

\begin{abstract}
Objectives: To study correlation between stress level and cortisol level with the number of dominant follicle at infertility patients underwent in vitro fertilization procedure

Materials and Methods: This study in an analytic cross sectional that held in two infertility clinic in Surabaya for four months. There were 30 research subjects with collected data about level stres using Percieved Stres Scale-10 (PSS-10) and Infertility Reaction Scale (IRS) scoring. Beside that the subjects also taken morning cortisol blood level. After that they underwent ovarial stimulation procedure and data about dominant follicel number collected before ovum pick up procedure

Results: Using statistic analysis Spearman correlation test, there was a negative correlation between stress level using PSS-10 $(\mathrm{r}=0,64 ; \mathrm{p}<0,01)$ and IRS $(\mathrm{r}=0,83 ; \mathrm{p}<0,01)$ scoring and follicle dominant number. The negative correlation also be found between cortisol level and follicle dominant number $(\mathrm{r}=0,80 \mathrm{p}<0,01)$.

Conclusions: The higher stress level someone measured by PSS10 and IRS scoring so the lower follicle dominant number. The Other result that the higher cortisol level so the lower follicle dominant number.
\end{abstract}

Keywords: Stress level, cortisol, follicle dominant

Correspondence: Awik Setiyono, Departemen Obstetri dan Ginekologi, Fakultas Kedokteran Universitas Airlangga Surabaya, RSUD Dr.Soetomo Surabaya, Telp.081-332900880, Email: awiksetiyono@yahoo.com

\section{PENDAHULUAN}

Infertilitas adalah keadaan dimana tidak terjadi kehamilan setelah periode satu tahun dengan hubungan seksual yang teratur tanpa menggunakan kontrasepsi. Di Amerika, tahun 2007 didapatkan prevalensi infertilitas pada wanita umur 20 hingga 44 tahun berkisar 9\%, sedangkan di Indonesia angka infertilitas pada pasangan usia reproduksi berkisar $12-15 \%$. $^{1,2}$

Infertilitas, selain disebabkan oleh faktor organ reproduksi pasangan suami istri, juga tak lepas dari adanya faktor stres.Saat tubuh merespon stres maka akan dihasilkan suatu hormon glukokortikoid yaitu kortisol dari kelenjar adrenal. Produksi hormon ini diatur oleh hipofisa berupa pengeluaran Adreno corticotrophine hormone $(\mathrm{ACTH})$. Stres menekan fungsi reproduksi melalui hambatan jalur Hipotalamus-Hipofisa-Gonad melalui penghambatan dari pelepasan hormon Gonadotropine-releasing hormone ( $\mathrm{GnRH})$. Di tingkat Hipofisa, efek dari kortisol merupakan efek sekunder dari penghambatan sekresi GnRH berupa penurunan produksi Follicle stimulating hormone (FSH) dan di tingkat ovarium, kortisol secara langsung menghambat produksi hormon steroid dan menginduksi apoptosis. ${ }^{3}$

Saat ini diketahui bahwa kortisol dan cortisol-binding protein (CBP) ada di dalam folikel dan merangsang berbagai mekanisme termasuk efek langsung steroidogenesis dan mempengaruhi kualitas oosit. ${ }^{4}$ Sarjana Matthiesen mengutip dari Lancastle dan Boivin menjelaskan bahwa penghambatan langsung kortisol terhadap estradiol akan mempengaruhi fungsi sel granulosa dan berdampak pada maturasi folikel dan berkurangnya jumlah oosit yang dapat dipetik.

Jumlah folikel yang berkembang dari folikel primordial menuju folikel antral di pengaruhi oleh respon folikel terhadap hormon FSH. Folikel yang merespon rangsangan $\mathrm{FSH}$ akan tumbuh dan berkembang hingga tahap proses maturasi. Kortisol dapat mengganggu pulsasi dari GnRH sehingga membuat kadar hormon 
FSH juga semakin turun dengan akibat jumlah folikel yang berkembang menjadi lebih sedikit. ${ }^{3}$

\section{BAHAN DAN METODE}

Penelitian ini dilakukan klinik infertilitas Graha Amerta RSUD Dr. Soetomo Surabaya dan klinik infertilitas RS Siloam Surabaya pada bulan Maret 2015 sampai Juni 2015 secara cross sectional. Subyek penelitian adalah pasien wanita dengan kausa infertilitas karena faktor tuba, endometriosis maupun kausa tidak terjelaskan dan atau memiliki pasangan infertil. Pasien wanita infertil memiliki rentang usia 20-35 tahun dengan siklus haid normal dan menjalani terapi fertilisasi in vitrodengan berbagai metode stimulasi ovarium.

Pasien yang setuju mengikuti penelitian akan dicatat mengenai data demografis dan data medis kemudian menandatangani lembar informed consent dan mengisi lembar skoring Perceived stress scale dan Infertility reaction scale. Pasien akan diambil sample darah $3 \mathrm{cc}$ untuk mengetahui kadar kortisol kemudian pasien akan menjalani stimulasi ovarium. Pada pasien kemudian dilakukan penghitungan jumlah folikel dominan sesaat sebelum dilakukan ovum pick up.

\section{HASIL DAN PEMBAHASAN}

Penderita yang memenuhi kriteria inklusi dan eksklusi sebanyak 30 orang. Rentang usia subyek penelitian 24 tahun sampai 34 tahun (rerata usia $=29,36 \pm 2,65$ ). Rerata waktu mengalami infertilitas adalah 5,3 tahun $(\mathrm{SD}=1,51)$. Semua subyek penelitian menjalani stimulasi ovarium dengan antagonis $\mathrm{GnRH}$ dalam prosedur fertilisasi in vitro-nya.

Tabel 1.Karakteristik Subyek Penelitian

\begin{tabular}{ccc}
\hline Karakteristik & Jumlah & Persentase \\
\hline Usia (thn) & & \\
$20-24$ & 1 & 3,3 \\
$25-29$ & 12 & 40 \\
$30-34$ & 17 & 56,7 \\
Pendidikan & & \\
SMP & 2 & 6,7 \\
SMA & 6 & 20 \\
Sarjana (S1/D3) & 22 & 73,3 \\
Bekerja & & \\
Ya & 22 & 73,3 \\
Tidak & 8 & 26,7 \\
Lama menikah & & \\
1-4 thn & 9 & 30 \\
5-9 thn & 21 & 70
\end{tabular}

$\operatorname{BMI}\left(\mathrm{Kg} / \mathrm{m}^{2}\right)$

\begin{tabular}{ccc}
$20-24,9$ & 27 & 90 \\
$25-29,9$ & 3 & 10 \\
Kausa Infertil & & \\
Endometriosis & 9 & 30 \\
Pria + tuba & 10 & 33,3 \\
Tuba & 6 & 20 \\
Tak jelas & 5 & 16,7 \\
\hline
\end{tabular}

Hasil dari 30 subyek penelitian terhadap tingkat stres secara umum (dengan mengisi kuisioner PSS-10) adalah sebanyak 12 orang (40\%) mengalami stres ringan, 17 orang $(56,7 \%)$ mengalami stres sedang dan hanya 1 orang $(3,3 \%)$ yang mengalami stres berat. Sedangkan untuk hasil pengisian kuisioner tingkat stres karena disebabkkan oleh penyebab infertilitasnya didapatkan hasil sebanyak 10 orang $(33,3 \%)$ mengalami stres ringan, 14 orang $(46,7 \%)$ mengalami stres sedang dan sisanya sebanyak 6 orang (20\%) mengalami stres berat. Pada ke-30 subyek penelitian didapatkan kadar kortisol terendah yang diukur adalah $7,23 \mu \mathrm{g} / \mathrm{dL}$ dan kadar tertinggi $112,40 \mu \mathrm{g} / \mathrm{dL}(\mathrm{SD}=32,7)$

Tabel 2. Kadar Kortisol dan Tingkat Stres

\begin{tabular}{|c|c|c|c|}
\hline \multirow[t]{2}{*}{ Stres } & \multirow[t]{2}{*}{ Jumlah } & \multicolumn{2}{|c|}{ Kortisol $(\mu \mathrm{g} / \mathrm{dL})$} \\
\hline & & Rerata & Rentang \\
\hline \multicolumn{4}{|l|}{ PSS-10 } \\
\hline Ringan & 12 & 19,82 & $7,23-28,34$ \\
\hline Sedang & 17 & 69,97 & $\begin{array}{c}27,87- \\
112,4\end{array}$ \\
\hline Berat & 1 & 80,75 & 80,75 \\
\hline \multicolumn{4}{|l|}{ IRS } \\
\hline Ringan & 10 & 20,77 & $7,66-45,89$ \\
\hline Sedang & 14 & 52,1 & $\begin{array}{c}22,45- \\
90,88\end{array}$ \\
\hline Berat & 6 & 95,18 & $\begin{array}{c}87,58- \\
112,4 \\
\end{array}$ \\
\hline
\end{tabular}

Pada ke-30 subyek penelitian didapatkan rentang penghitungan jumlah folikel dominan 3-12 buah.

Tabel 3. Tingkat stres dan Folikel Dominan

\begin{tabular}{cccc}
\hline Stres & Jumlah & \multicolumn{2}{c}{ Folikel Dominan (Buah) } \\
& & Rerata & Rentang \\
\hline PSS-10 & 12 & 9 & $5-12$ \\
Ringan & 17 & 5 & $3-8$ \\
Sedang & 1 & 5 & 5 \\
Berat & & & \\
IRS & 10 & 9,7 & $6-12$ \\
Ringan & 14 & 5,57 & $3-7$ \\
Sedang & 6 & 3,8 & $3-5$ \\
Berat & & & \\
\hline
\end{tabular}

Hasil analisa statistik menunjukkan adanya hubungan negatif antara tingkat stres umum dengan jumlah folikel dominan $(r=0,64 ; p<0,01)$ begitu juga adanya hubungan negatif antara tingkat stres spesifik infertilitas (skoring IRS) dengan jumlah folikel dominan $(r=0,83 ; \mathrm{p}<0,01)$. 
Dari hasil analisa statistik didapatkan adanya hubungan negatif antara kadar kortisol dengan jumlah folikel dominan $(r=0,80 ; p<0,01)$. Sebaran data pada Gambar 1 menunjukkan bahwa semakin tinggi kadar kortisol dalam darah maka semakin sedikit jumlah folikel dominan.

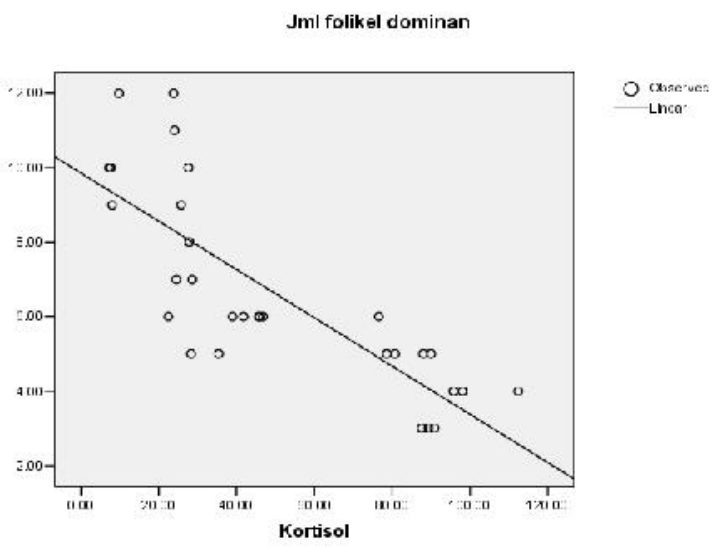

Gambar 1. Sebaran Data Kadar Kortisol dan Jumlah Folikel Dominan

\section{Karakteristik subyek penelitian}

Pada penelitian ini, total 30 subyek, memiliki rentang usia 24 sampai dengan 34 tahun dengan rata-rata usia 29,3 tahun $(\mathrm{SD}=2,65)$. American Society for Reproductive Medicines (2006) menjelaskan pada wanita kelompok umur 20-29 tahun memiliki tingkat infertilitas $8 \%$ dan akan meningkat menjadi $14,6 \%$ pada kelompok usia 30-34 tahun. ${ }^{6}$ Lama menikah juga dapat memberikan stres tersendiri bagi pasangan yang ingin memiliki keturunan. Pada subyek penelitian ini didapat-kan ratarata lama menikah 5,3 tahun dengan rentang antara 2 sampai 8 tahun. Lama paparan untuk hamil berbanding terbalik dengan kesuburannya. Penelitian yang dilakukan Aucky Hinting (2001) menyebutkan pada perawatan infertilitas secara konvensional didapatkan angka kehamilan kumulatif $56,8 \%$ pada pasangan dengan lama menikah 1 tahun, 32\% pada lama menikah sampai 2 tahun, 29,9\% pada pasangan yang menikah 3 tahun dan $23,3 \%$ pada lama menikah 4 tahun. ${ }^{1}$

Pada penelitian ini didapatkan BMI dari subyek penelitian rata-rata $22,7 \mathrm{~kg} / \mathrm{m}^{2}$ Homan (2007) mengatakan bahwa obesitas dapat berpengaruh terhadap fungsi reproduksi dengan cara menyebabkan ketidakseimbangan hormonal dan disfungsi ovulasi. ${ }^{7}$ Jadi dapat disimpulkan bahwa pada penelitian ini dapat disingkirkan pengaruh obesitas sebagai faktor penyebab infertilitas.

\section{Hubungan tingkat stres dan jumlah folikel dominan}

Tingkat stres yang diukur dengan menggunakan kuisioner merupakan parameter sederhana yang dipakai untuk mengetahui seseorang sedang mengalami stres atau tidak. ${ }^{8}$ Skoring PSS-10 banyak digunakan untuk menilai hubungan antara tingkat stres dengan keberhasilan prosedur fertilisasi in vitro, pada penelitian Turner (2013), dengan menggunakan model logistik regresi, nilai skor PSS-10 yang rendah (cut off 11) pada 1 hari sebelum dilakukan pengambilan oosit memiilki tingkat kehamilan yang lebih baik $(\mathrm{p}=0,03) .{ }^{9}$ Penelitian yang hampir sama juga dilakukan oleh Cohen (2001) dimana pada penelitian tersebut dihasilkan penurunan $7 \%$ oosit yang dipanen pada subyek dengan peningkatan skoring PSS-10 namun secara statistik tidak bermakna $(\mathrm{p}=0,06) .{ }^{10}$

Pada penelitian ini pada pengunaan skoring dengan IRS dengan jumlah subyek yang lebih merata pada masingmasing tingkatan stres didapatkan hasil yang secara klinis dan statistik signifikan antara tingkatan stres ringan, sedang dan berat dengan rerata jumlah folikel dominan 9,7 buah, 5,57 buah dan 3,8 buah. Hasil ini menjadikan skoring IRS memiliki tingkat kemaknaan hubungan yang lebih baik antara tingkat stres dan jumlah folikel dominan bila dibandingkan dengan penggunaan skoring PSS-10 ( $r=0.8$ vs $r=0,6 ; \mathrm{p}<0,01)$. Studi oleh Greil et al (2011), parameter dalam skoring stres umum berguna dalam membandingkan antara wanita tidak stres dan populasi lain. Parameter skoring spesifik infertilitas sangat cocok dalam assessment variabilitas diantara wanita infertiltas. Skoring infertilitas cocok digunakan praktek klinis untuk identifikasi wanita yang stres karena infertilitas. ${ }^{11}$

\section{Hubungan kadar kortisol dan jumlah folikel dominan}

Pada penelitian ini didapatkan hubungan negatif antara tingkat stres dan kadar kortisol dengan jumlah folikel dominan. Hasil ini menunjukkan bahwa semakin tinggi kadar kortisol seseorang maka jumlah folikel dominan akan berkurang $(\mathrm{r}=0,80 \mathrm{p}<0,01)$. Hipotesis studi ini adalah ada hubungan semakin tinggi kadar kortisol dengan semakin sedikitnya jumlah folikel dominan sehingga hipotesis penelitian diterima sesuai hasil analisa statistik.

Kortisol mempengaruhi pulsasi dari GnRH sehingga produksi FSH menjadi berkurang. Hormon FSH (Follicle Stimulating Hormone) memilikiperan yang dominan saat perkembangan awal dari folikel, yaitu sejak menjadi folikel antral hingga menjadi folikel dominan. Pada stadium antral, folikel sangat bergantung 
dengan gonadotropin. Hipotalamus menghasilkan Gonadotropin Releasing Hormone ( $\mathrm{GnRH}$ ) yang merangsang hipofisis anterior untuk melepaskan FSH. Folikel tersebut makin tumbuh besar atas pengaruh FSH. Selanjutnya akan terjadi seleksi dimana folikel dominan bertahan karena umpan balik inhibisi sekresi FSH oleh estrogen dan inhibin. Meskipun dengan penurunan FSH, folikel dominan akan bertahan karena beberapa mekanisme antara lain banyaknya kandungan reseptor FSH sehingga folikel tersebut lebih sensitif terhadap FSH. Pada akhirnya hanya satu folikel yang mampu bertahan dan tumbuh hingga lebih dari $20 \mathrm{~mm}$ yang disebut folikel dominan. ${ }^{13,14,15}$

Studi yang dilakukan pada Daley (1999), mengenai efek stres dari kortisol pada perkembangan awal folikel domba menunjukkan bahwa kortisol menghambat perkembangan dan pertumbuhan awal folikel. Konsentrasi kortisol pada saat stres menghambat folikulogenesis secara langsung pada ovarium. Selain itu, kortisol berpengaruh pada sekresi gonadotropin sehingga menghambat pengeluaran FSH untuk perkembangan folikel. ${ }^{15}$

Pada fase awal perkembangan folikel, jumlah berlebih dari kortisol dapat mengganggu fungsi sel granulosa yang dirangsang oleh FSH, sehingga pada periode ini oksidasi kortisol melalui enzim $11 \beta$-HSD tipe 2 sangat diperlukan. ${ }^{16}$ Shannon Whirledge dan John A. Cidlowski (2010) memberikan penjelasan yang hampir sama mengenai peran glukokortikoid terhadap folikel. Di dalam ovarium, 11 $\beta$-HSD1 dan $11 \beta$-HSD2 dibentuk secara teratur. Secara spesifik, sel granulosa yang tidak mengalami lonjakan LH mendekati ovulasi mengekspresikan 11 $\beta$-HSD2 ini, sedangkan sel granulosa terluteinisasi mengekspresikan $11 \beta$-HSD1 dan tak dapat mendeteksi ekspresi $11 \beta$-HSD2. ${ }^{3}$

Data ini menunjukkan kadar kortisol aktif ditekan selama perkembangan awal folikel dan akan meningkat saat mengalami proses ovulasi yang dipicu oleh lonjakan LH. Kortisol beraksi langsung terhadap sel ovarium melalui penghambatan kerja LHdan biosintesa dari steroid. Pada kultur sel granulosalutein manusia, kortisol menghambat steriodogenesis yang distimulasi LH berdasarkan konsentrasinya dan interaksi ini dimodulasi oleh 11 $\beta$-HSD. Pada kultur sel granulosa tikus, kortisol menekan aktivitas FSH yang diinduksi $\mathrm{P} 450$ aromatase dan jumlah reseptor $\mathrm{FSH}^{3,12}$

\section{SIMPULAN}

Tingkat stres yang tinggi pada seseorang menyebabkan tingginya kadar kortisol dalam darah. Hal ini dapat berpengaruh pada poros $\mathrm{H}-\mathrm{P}-\mathrm{O}$ dengan akibat menurun- nya jumlah folikel dominan. Semakin tinggi tingkat stres dan kadar kortisol maka akan semakin rendah jumlah folikel dominan.

\section{DAFTAR PUSTAKA}

1. Samsulhadi. Selayang pandang infertilitas: Penatalaksanaan infertilitas praktis dan terkini (Pada praktek keseharian berbasis bukti klinis). Pendidikan kedokteran berkelanjutan bidang fertilitas dan endokrinologi reproduksi. Surabaya. 2012. hal. 3-5.

2. Speroff L, Fritz MA. Female infertility in : Clinical Gynecologic Endocrinology and Infertility. 8th Eds. USA: Lippincott Williams \& Wilkins; 2011. p. 1137-40.

3. Whirledge S, Cidlowski JA. Glucocorticoids, stress, and fertility. National Institute of Health. Minerva endocrinol. 2010;35(2):109-25.

4. Yding AC, et al. Assessment of the follicular cortisol: cortisone ratio. Hum Reprod. 1999;14 (6):1563-8.

5. Matthiesen SMS, Frederiksen Y, Ingerslev HJ. Stress, Distress, and Outcome of Assisted Reproductive Technology (ART): A meta-analysis. Hum Reprod. 2011;26(10):2763-76.

6. Hoffman BL, Schorge JO, Schaffer JI, Halvorson LM, Bradshaw KD, Cunningham FG. Evaluation of the infertile couple in: Williams Gynecology. 2nd Eds. New york: McGraw Hill; 2012. p. 507-20.

7. Homan GF, Davies M, Norman R. The impact of lifestyle factors on reproductive performance in the general population and those undergoing infertility treatment: A review. Hum Reprod Rev. 2007;13 (13):209-23.

8. Ibrahim AS. Mengenal Stres dalam Stres dan psikosomatis. Jakarta: Dua AS-I-Dua AS; 2003. hal. 31-80.

9. Turner K, Reynolds-May MF, Zitek EM, Tisdale RL, Carlisle AB, Westhpal LM. Stress and Anxiety Scores in First and Repeat IVF cycles: A Pilot Study. Plos One. 2013;8(5):1-6.

10. Klonoff-Cohen H, Chu E, Natarajan L, Sieber W. A prospective study of stress among women undergoing in vitro fertilization or gamete intrafallopian transfer. Fertility \& Sterility. 2001;76(4):675-85.

11. Greil AL, Shreffler KM, Schmidt L, McQuillan J. Variation in distress among women with infertility: evidence from a population-based sample. Hum Reprod. 2011;26(8):2101-12.

12. Bider D, Shine S, Tur-kaspa I, Levron J, Dor J. Cortisol concentrations in follicular fluid of 'low responder' patients. Hum Reprod. 1998;13(1):27-9.

13. Samsulhadi, Hendarto H. Aplikasiklinis: Induksi Ovulasi \& Stimulasi Ovarium. Himpunan Fertilitas 
Endokronologi reproduksi Perkumpulan Obstetri \& Ginekologi Indonesia. Edisi ke-1. Jakarta: SagungSeto; 2009.

14. Speroff L, Fritz MA. Regulation of the menstrual cycle in: Clinical Gynecologic Endocrinology and Infertility. 8th Eds. USA: Lippincott Williams \& Wilkins; 2011. p. 200-10.
15. Daley CA, Macfarlane MS, Sakurai H, Adams TE. Effects of stres-like concentrations of cortisol on follicular development and the preovulatory surge of LH in sheep. Journal of Reproduction and Fertility. 1999;117:11-6.

16. Lewicka S, et al.Cortisol and cortisone in human follicular fluid and serum and the outcome of IVF treatment. Hum Reprod. 2003;18(8):1613-7. 